\title{
The intestinal tract as the major source of interleukin 6 production during abdominal aortic clamping and hind limb ischaemia-reperfusion injury ${ }^{1}$
}

\author{
O trato intestinal como a principal fonte na producao de interleucina 6 durante \\ clampeamento da aorta abdominal e lesão de isquemia/rererfusão de membros \\ inferiores
}

\begin{abstract}
Márcio Benedito Palma Pimenta ${ }^{2}$, José Eduardo de Aguilar-Nascimento ${ }^{3}$, Dely Cristina Martins ${ }^{4}$, Daniele Ribastski da Silva $^{5}$, Kátia Leston Bacelo ${ }^{5}$, Isabel Cristina Bocchese ${ }^{5}$, Sarai Zaffani ${ }^{6}$, Elieser Zaffani ${ }^{6}$, Érika Alessandra Oliveira Silveira $^{6}$, Aracelle Victor do Carmo ${ }^{6}$, Simone Sampaio Saldanha Ferreira ${ }^{6}$.
\end{abstract}

1. Department of Surgery; Federal University of Mato Grosso, Cuiabá, MT, Brazil.

2. Master, Assistant Professor, Department of Surgery, Federal University of Mato Grosso Brazil.

3. MD, PhD, Chairman Full Professor, Department of Surgery, Federal University of Mato Grosso Brazil.

4. MD, PhD, Associate Professor Department of Pathology, Federal University of Mato Grosso Brazil.

5. Biochemistry, Hospital Santa Rosa, Cuiaba, MT, Brazil.

6. Medical student, Federal University of Mato Grosso, Cuiabá, MT, Brazil

\begin{abstract}
Purpose: The aim of this study was to investigate whether the hind limbs or intestinal tract is the most important initiator of the inflammatory response secondary aortic clamping and hind limb ischemia/reperfusion injury. Methods: Blood samples of Wistar rats obtained from posterior cava vein, portal vein, and heart cavity during either laparotomy (control group, $\mathrm{n}=8$ ) or laparotomy $+2 \mathrm{~h}$ of aortic clamping and bilateral hind limb ischemia (ischemia group, $\mathrm{n}=8$ ), or $2 \mathrm{~h}$ after ischemia and $2 \mathrm{~h}$ of reperfusion (ischemia-reperfusion group, $\mathrm{n}=8$ ) were assayed for interleukin 6 (IL-6) and C-reactive protein (CRP). Results: Serum IL-6 at the heart $(223.6 \pm 197.9$ [10-832] pg/mL) was higher $(\mathrm{p}<0.001)$ than at both portal (133.08 \pm 108.52 [4-372] pg/mL) and posterior cava veins (127.58 \pm 109.15 [8-388] pg/mL). CRP was not significant different among groups. Conclusion: The splanchnic region is also a source of inflammatory response secondary to ischemia and reperfusion of the hind limbs.
\end{abstract}

Key words: Ischemia. IL-6. 3.C-reactive protein. Mucosa. Inflammation.

\section{RESUMO}

Objetivo: Investigar qual o principal mediador da resposta inflamatória na lesao de isquemia/reperfusão após clampeamento da aorta abdominal e isquemia dos membros inferiores: o intestine ou as extremidades inferiores. Métodos: amostra de sangue de ratos Wistar coletados da cava posterior, porta e cavidade cardíaca during tanto laparotomia (grupo controle $\mathrm{n}=8$ ) ou laparotomia +2 horas de clampeamento aórtico e isquemia bilateral de membros posteriores (grupo isquemia $\mathrm{n}=8$ ), ou $2 \mathrm{~h}$ de isquemia seguido por 2 horas de reperfusão (grupo isquemia/reperfusão $\mathrm{n}=8$ ), onde foram dosados interleucina 6 e proteína C-reativa. Resultados: Il-6 no coração (223.6 \pm 197.9 [10-832] pg/ $\mathrm{mL})$ foi maior $(\mathrm{p}<0.001)$ tanto na veia porta $(133.08 \pm 108.52[4-372] \mathrm{pg} / \mathrm{mL})$ quanto na veia cava posterior $(127.58 \pm 109.15$ [8-388] pg/mL). PCR não foi significativamente diferente entre os grupos. Conclusão: o trato intestinal foi responsável pela resposta inflamatória secundária a lesão de isquemia/reperfusão.

Descritores: Isquemia. IL-6. Proteina C-reativa. Mucosa. Inflamação. 


\section{Introduction}

The prevalence of abdominal aortic aneurysm (AAA) is estimated at $3 \%$ of the male population above 50 , and is the cause of $2 \%$ of deaths in men over the age of 65 years $^{1-4}$. When AAA is identified and the patient operated on before rupture, the mortality rate is approximately $5 \%$, the cause of death generally resulting from cardiac complications ${ }^{5}$. Unfortunately when AAA is operated on an emergency basis (due to rupture), the mortality rate is at least $50 \%$. In this case, multiple organ failure (MOF) is the main cause of death ${ }^{6,7}$. Heterogeneous traumatic stimuli may progress to a state of systemic inflammatory response (SIRS-Systemic Inflammatory Response Syndrome). The diagnosis of SIRS can be made on a clinical basis using established clinical parameters ${ }^{8}$. The initial inflammatory response to injury is presumed to be beneficial for restoring the patient's homeostasis. However, if it is either exaggerated or perpetuated, the patient may enter a state of malignant systemic inflammation that may progress to $\mathrm{MOF}^{9}$. The activation of the cytokine cascade after a trauma has been amply studied. The role of some cytokines such as the tumoral necrosis factor alpha (TNF- $\alpha$ ), and interleukines 1 (IL-1) and 6 (IL-6) after an insult is wellestablished $^{10-12}$. Serum IL-6 is a good marker to predict the clinical evolution and the outcome of a patient with major trauma. High levels of IL-6 after trauma correlate with increasing incidence of complications ${ }^{13-15}$. IL-6 is the main regulating factor for the liver production of acute phase proteins including C-reactive protein (CRP). Although CRP serum levels seem to have direct correlation with acute inflammation ${ }^{16-18}$, it has not been studied in experimental models of ischemia/reperfusion injury. The inflammatory response in AAA repair is peculiar when compared to other major surgical procedures due to the ischemia of region located under the aortic clamping. In accordance, a generalized and potentially deleterious systemic inflammatory response is well documented in patients submitted to AAA repair ${ }^{10,}$ ${ }^{11}$. The exact origin of the inflammatory mediators during AAA repair remains obscure despite the fact that both the inferior limbs and the intestinal tract are the tissues most subject to the ischemia/reperfusion injuries due to the aortic clamping ${ }^{19-21}$. We speculate that the intestinal tract may contribute to systemic inflammatory response during AAA repair. During operation, intestinal manipulation, hypothermia, mesenteric traction, and direct intestinal ischaemia might play a role in the production of inflammatory mediators. Moreover, bacterial translocation has been pointed out as a contributing cause of MOF after AAA repair ${ }^{22-26}$. In this context however, various questions remain unanswered. Thus, it would be plausible to investigate which region or organ is responsible for the initiation and/or perpetuation of SIRS in the AAA surgical repair. Would it be the inferior limbs, the splanchnic region or both? Is the production of inflammatory mediators by the splanchnic region predominant over mediators arising from inferior limbs? Based on these questions we aimed at investigating the source of inflammatory mediators in an experimental model of ischemia/reperfusion injury similar to the AAA repair. A second objective was to compare the effect of ischemia and ischemia associated with reperfusion on both the production of inflammatory mediators and gut mucosal.

\section{Methods}

\section{Animals}

Twenty-four male Wistar rats (280-320 g) obtained from the biotery of the Federal University of Mato Grosso entered the study. They were kept in metabolic cages at the laboratory environment in 12-h light/dark cycles at a mean temperature of $75.2^{\circ} \mathrm{F}\left(24^{\circ} \mathrm{C}\right)$ one day prior to the beginning of the experiment. They had free access to tap water and standard rat chow ad libitum. The experiment followed the guidelines and ethical rules of the Brazilian College for Animal Experimentation (COBEA) adopted by the laboratory. The study was divided in Experiment I and Experiment II with 24 animals each.

Cytokine response after ischemia/reperfusion injury.

Twenty-four animals were randomized into three groups: control $(n=8)$, ischemia $(n=8)$ and ischemia/ reperfusion $(n=8)$. After 12 hours fasting, the animals were weighted and submitted to inhalatory general anesthesia with ether followed by $4 \mathrm{~cm}$ median laparotomy. All animals received subcutaneous injection of sterile $0.9 \%$ saline $(3 \mathrm{~mL} / \mathrm{kg} / \mathrm{h})$ as intra-operative hydration. At the end of the procedure, all animals were killed with an overdose of inhalatory ether. Immediately after the laparotomy, we took blood samples from the posterior cava vein, portal vein, and directly from the cardiac cavity in animals of the control group. In the other two groups, the abdominal aorta distal to the renal arteries (and consequently distal to the superior mesenteric artery and celiac, artery which irrigate the gut) was dissected and then occluded with a Bulldog clamp. At the same time, we induced bilateral hind limb ischemia by applying latex rubber band tourniquets around both thighs. Blood samples were collected in the same three sites as described for control group after either $2 \mathrm{~h}$ of ischemia (ischemia group) or $2 \mathrm{~h}$ of ischemia and $2 \mathrm{~h}$ of reperfusion (ischemia-reperfusion group). Blood samples were centrifuged and the serum frozen at $68^{\circ} \mathrm{F}\left(-20^{\circ} \mathrm{C}\right)$ and finally assayed for IL-6 and CRP. 


\section{Serum IL-6}

IL-6 was quantified using ELISA "solid phase sandwich” kit (Biosource International Inc., Camarillo CA, USA), following the protocol provided by the manufacturer. Briefly, the supplied plate had a specific antibody against rat IL-6. The examined serum sample in contact with the plate formed the antigen-antibody complex. The enzyme Streptavidin-Peroxidase joined this complex. Finally, a color substratum was added in order to link to the enzyme. The color intensity of this product which is directly proportional to the concentration of IL6 in the original sample was read by a spectrophotometer $(450 \mathrm{~nm})$. The result was expressed in $\mathrm{pg} / \mathrm{mL}$.

\section{Serum C-reactive protein}

The imunoturbidimetric method with latex was used for a quantitative dosage of the CRP. CRP from the sample (linked the latex particles) was covered with anti-CRP antibodies. The turbidity caused by the coalescence of latex particles which is proportional to the concentration of CRP in the sample was measured by a spectrophotometer $(600 \mathrm{~nm})$. The procedure was done in an automated device (model BT 3000 plus, Wiener lab. 2000 Rosário - Argentina) using the Linea turbitest AA PCR látex kit from the same above manufacturer. The result was expressed in $\mathrm{pg} / \mathrm{mL}$.

\section{Statistical analysis}

Both serum CRP and IL-6 values were treated by the repeated measures ANOVA to compare the site of collection (within-subject analysis) and groups (betweensubject analysis. When a significant difference was observed, either the Tukey's test (to compare groups) or the Wilcoxon test (to compare sites) was used. One-way ANOVA was used to compare body weight.. The level of statistical significance was established at 5\% (pd”0,05). Results expressed as either mean \pm standard deviation [range] or median (range), as appropriated. In figures, error bars represent the standard error mean (SEM). Analysis done by the statistical package SPSS for Windows 8.0 .

\section{Results}

Weight

Body weight of the animals of the three groups was statistically similar (control group $=304 \pm 17$ [290-330]g; ischemia group $=306 \pm 10$ [295-320]g; group ischemia/ reperfusion $=310 \pm 13$ [295-330] g; $\mathrm{p}=0.46$ ).

\section{Influence of ischemia and reperfusion}

Serum IL-6 was higher after both ischemia/ reperfusion $(267 \pm 29$ [206.5-327.6] pg/mL; $<<0.001)$ and ischemia alone $(169 \pm 29$ [108.5-229.6] $\mathrm{pg} / \mathrm{mL} ; \mathrm{p}=0.02)$ when compared to control rats $(48 \pm 29$ [12.4-108.2] pg/ $\mathrm{mL}$ ). The difference between ischemia/reperfusion group and ischemia group was marginally significant $(\mathrm{p}=0.06)$. There was no interaction with the collection site $(p=0.72)$. Results are showed in figure 1. Serum CRP was not different among the three groups (control group = $0.027 \pm 0.005[0.016-0.038] \mathrm{pg} / \mathrm{dL}$,), ischemia group $=$ $0.035 \pm 0.005[0.02 .4-0.04 .6] \mathrm{pg} / \mathrm{dL}$, and ischemia/ reperfusion group $=0.018 \pm 0.005[0.074-0.029] \mathrm{pg} / \mathrm{dL}$; $\mathrm{p}=0.07$ ), and there was no statistical interaction with site of collection.

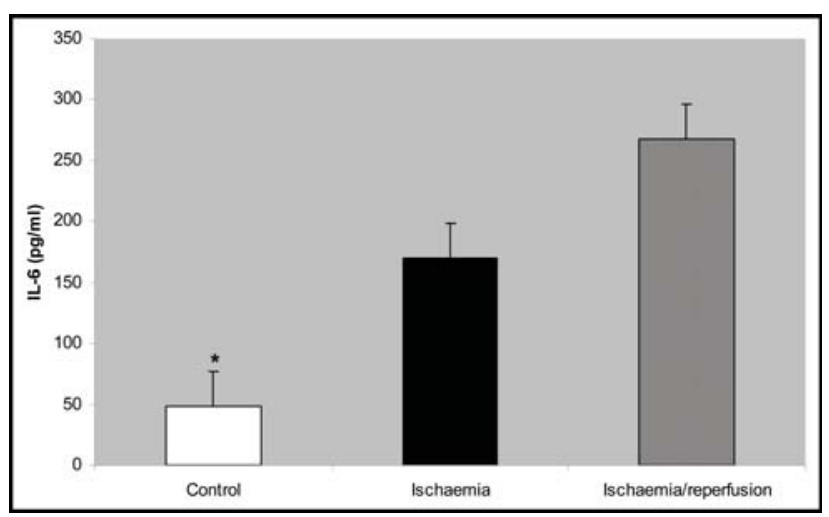

FIGURE 1 - Serum IL-6 in the three groups. Data represent the mean and the SEM. *, $\mathrm{p}=0.02$ versus ischemia group, and $\mathrm{p}<0.001$ versus ischemia/ reperfusion group.

\section{Influence of the site of blood collection}

The findings of serum IL-6 levels according to the collection site can be seen in figure 2 . The data showed that IL-6 levels were influenced by the collection site $(\mathrm{p}<0.01)$ and this finding occurred similarly in all groups $(\mathrm{p}=0.43)$. Serum IL-6 in samples collected at the heart cavity (223.6 \pm 197.9 [10-832] pg/mL,) was higher than both portal $(133.08 \pm 108.52$ [4-372] pg/mL, $<<0.01)$ and posterior cava veins (127.58 \pm 109.15 [8-388] pg/mL; $\mathrm{p}=0.01)$. Serum IL-6 at posterior cava vein was similar to portal vein. Serum CRP however did not vary according to the collection site $(p=0.90)$. Results are showed in figure 2 . 


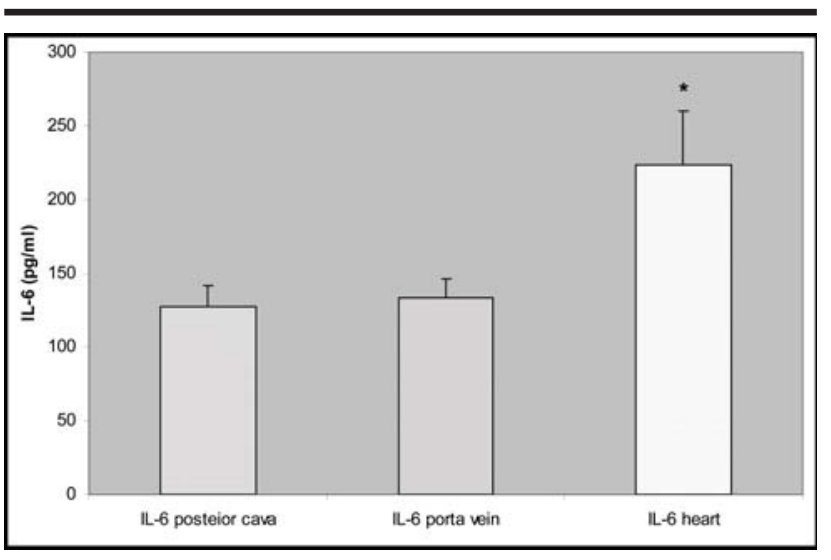

FIGURE 2 - Serum IL-6 level in the three collection sites. Data express the mean and the SEM*, $\mathrm{p}<0.01$ versus both portal and posterior cava vein.

\section{Discussion}

The findings in the present study suggest that the inflammatory response mediated by IL-6 in this animal model of aortic clamping and hind limbs ischemia arise from both the splanchnic region and the hind limbs. The high levels of serum IL-6 observed at both portal and posterior cava veins in animals underwent either ischemia or ischemia/reperfusion are in line with this assumption. IL-6 levels at the heart cavity were higher than the observed in the other two sites. This seems plausible since it would reflect the sum of this cytokine emerging from both splanchnic and hind limbs territories. Ischemic lower limbs have are presumed to be the source of inflammatory mediators in ischemia/reperfusion injury after aortic clamping. In fact, serum IL-6 significantly augments at the femoral vein than at the systemic circulation in patients during AAA repair ${ }^{19}$. Patients subjected to open AAA surgical repair have endothelial activation and accumulation of activated neutrophils in muscles as a result of ischemia/reperfusion injury ${ }^{27,28}$. This evidence suggests that the inferior members are the source of inflammation in ischemia/reperfusion injury. In accordance, our results showed an increase of IL-6 at the posterior cava vein. The initiation of inflammation at the lower extremities may damage the gut. Experimental studies in rats suggest that isolated ischemia of the hind limbs increases intestinal permeability ${ }^{29,30}$, promotes endotoxemy ${ }^{31}$, decreases the splanchnic blood flow ${ }^{32}$, leads to oxidative stress ${ }^{33}$, and generates gut morphological change ${ }^{30}$. Bacterial translocation may occur due to this indirect injury through the ileal mucosal barrier $^{30}$. Even though there is no evidence that bacterial translocation occurs clinically on a significant scale, endotoxemy has been demonstrated both in experimental and clinical studies in open AAA repair ${ }^{29,30,31}$. Splanchnic region may contribute with inflammatory mediators in AAA repair. High levels of IL-6 and low levels of endotoxin have been reported in mesenteric stream during open AAA repair ${ }^{34}$. High levels of endotoxin can be found after intestinal manipulation even before aortic clamping ${ }^{22}$. During aortic surgery, levels of both TNF alpha and endotoxins in the portal vein are higher when compared to systemic blood samples ${ }^{26}$. Our findings support the evidence that ischemia/reperfusion injury of the limbs may affect the gut and the splanchnic region. We found an increase in IL-6 levels at the portal. Moreover, manipulation of the bowel, mesenteric traction and cooling, direct ischemia caused by vascular clamping, and definitive interruption of the inferior mesenteric and iliac arteries may directly damage the gut ${ }^{22-26}$. In accordance, neutrophil activation, systemic inflammatory response and organ dysfunction are increased in elective AAA repair when transperitoneal is compared with extraperitoneal approach ${ }^{36}$. Although some authors suggest that the intestinal tract would be an important source of inflammation during AAA repair ${ }^{26,36,37}$ one clinical study did not find differences in both IL-6 and IL-10 levels when femoral vein samples were compared to systemic blood samples in patients submitted to AAA open repair ${ }^{21}$. In contrast, our experiment showed that IL-6 levels found in the posterior cava vein were similar to those found in portal vein and both were lower than in samples collected at the heart (systemic blood). Thus, our findings suggest that the source of the inflammatory process in this model are part from direct ischemia of hind limbs (posterior cava) and part from the splanchnic region (portal vein) which was not directly influenced by the ischaemia and reperfusion injury. Serum CRP levels did not differ among the three groups. IL-6 is the main regulator of the production of acute phase proteins such as CRP during inflammatory response. CRP plays an important role in the opsonization ${ }^{16-18}$. We speculate that in this model the similar levels of CRP found in the three groups reflected the time points of the study. Samples were collected earlier and thus, it is plausible to assume that if the animals were kept alive for another few hours the increase of CRP could become evident. The overall results showed that the inflammatory process in this model of aorta clamping and hind limbs ischemia is originated both at the splanchnic region and ischemic hind limbs. The magnitude of this reaction according to the elevation of IL-6 seems to be similar in both regions. This is relevant and suggests that the intestine is an important motor of SIRS even though the main target of the ischemia/reperfusion injury was distant. In this model of ischemia/reperfusion injury we were not able to ascertain the trigger for the intestinal tract production of IL-6. Thus, further studies are necessary. In conclusion, abdominal aortic clamping distal to the renal arteries in association with ischemia of hind limbs causes enhanced systemic inflammatory response that is partly initiated at the splanchnic region that contribute similarly to the ischemic hind limbs for the strength of the inflammatory response. 


\section{References}

1. Turk KAD The post-mortem incidence of abdominal aortic aneurysm. Proc R Soc Med. 1965; 58:869-70.

2. Allen PI, Gourevitch D, McKinley J, Tudway D, Goldman M. Population screening for aortic aneurysms. Lancet. 1987; 2:736.

3. Collin J, Araujo L, Walton J, Lindsell D. Oxford screening programme for abdominal aortic aneurysm in men aged 65 to 74 years. Lancet. 1988; 2:613-5.

4. St Leger AS, Spencely M, McCollum CN, Mossa M. Screening for abdominal aortic aneurysm: a computer assisted cost-utility analysis. Eur J Vasc Endovasc Surg. 1996; 11:183-90.

5. Anomymous. Mortality results for randomised controlled trial of early elective surgery or ultrasonographic surveillance for small abdominal aortic aneurysms. The UK Small Aneurysm Trial Participants. Lancet. 1998; 352:1649-55.

6. Sayers RD, Thompson MM, Nasim A, Healey P, Taub N, Bell PR. Surgical management of 671 abdominal aortic aneurysms: a 13 year review from a single centre. Eur J Vasc Endovasc Surg. 1997; 13:322-7.

7. Meesters RC, van der Graaf Y, Vos A, Eikelboom BC. Ruptured aortic aneurysm: early postoperative prediction of mortality using an organ system failure score. Br J Surg. 1994; 81:512-6.

8. Bone RC, Balk RA, Cerra FB, Dellinger RP, Fein AM, Knaus WA, Schein RM, Sibbald WJ. Definitions for sepsis and organ failure and guidelines for the use of innovative therapies in sepsis. The ACCP/SCCM Consensus Conference Committee. American College of Chest Physicians/Society of Critical Care Medicine. Chest. 1992; 101:1644-55.

9. Fry DE, Pearlstein L, Fulton RL, Polk HC Jr. Multiple system organ failure. The role of uncontrolled infection. Arch Surg. 1980;115: 136-40.

10. Giannoudis PV. Current concepts of the inflammatory response after major trauma: an update. Injury. 2003; 34:397-404.

11. Norwood MG, Bown MJ, Sayers RD. Ischaemiareperfusion injury and regional inflammatory responses in abdominal aortic aneurysm repair. Eur J Vasc Endovasc Surg. 2004; 28:234-45.

12. Eltzschig HK, Collard CD. Vascular ischaemia and reperfusion injury. Br Med Bull. 2004;70: 71-86.

13. Damas P, Ledoux D, Nys M, Vrindts Y, De Groote D, Franchimont P, Lamy M. Cytokine serum level during severe sepsis in human IL-6 as a marker of severity. Ann Surg. 1992; 215:356-62.

14. Muehlstedt SG, Richardson CJ, Lyte M, Rodriguez JL. Systemic and pulmonary effector cell function after injury. Crit Care Med. 2002; 30:1322-6.
15. Pape HC, van Griensven M, Rice J, Gansslen A, Hildebrand F, Zech S, Winny M, Lichtinghagen R, Krettek C. Major secondary surgery in blunt trauma patients and perioperative cytokine liberation: determination of the clinical relevance of biochemical markers. J Trauma. 2001; 50:989-1000.

16. Waydhas C, Nast-Kolb D, Trupka A, Zettl R, Kick M, Wiesholler J, Schweiberer L, Jochum M. Posttraumatic inflammatory response, secondary operations, and late multiple organ failure. J Trauma. 1996; 40:624-31.

17. Giannoudis PV, Smith MR, Evans RT, Bellamy MC, Guillou PJ. Serum CRP and IL-6 levels after trauma. Not predictive of septic complications in 31 patients. Acta Orthop Scand. 1998; 69:184-8.

18. Mimoz O, Benoist JF, Edouard AR, Assicot M, Bohuon C, Samii K. Procalcitonin and C-reactive protein during the early posttraumatic systemic inflammatory response syndrome. Intensive Care Med. 1998; 24:185-8.

19. Rowlands TE, Homer-Vanniasinkam S. Pro- and antiinflammatory cytokine release in open versus endovascular repair of abdominal aortic aneurysm. Br J Surg. 2001; 88:1335-40.

20. Thompson MM, Nasim A, Sayers RD, Thompson J, Smith G, Lunec J, Bell PR. Oxygen free radical and cytokine generation during endovascular and conventional aneurysm repair. Eur J Vasc Endovasc Surg. 1996; 12:70-5.

21. Holmberg A, Bergqvist D, Westman B, Siegbahn A. Cytokine and fibrinogen response in patients undergoing open abdominal aortic aneurysm surgery. Eur J Vasc Endovasc Surg. 1999; 17:294-300.

22. Lau LL, Halliday MI, Lee B, Hannon RJ, Gardiner KR, Soong CV. Intestinal manipulation during elective aortic aneurysm surgery leads to portal endotoxaemia and mucosal barrier dysfunction. Eur J Vasc Endovasc Surg. 2000; 19:619-24.

23. Ernst CB, Hagihara PF, Daugherty ME, Griffen WO Jr. Inferior mesenteric artery stump pressure: a reliable index for safe IMA ligation during abdominal aortic aneurysmectomy. Ann Surg. 1978; 187:641-6.

24. Piotrowski JJ, Ripepi AJ, Yuhas JP, Alexander JJ, Brandt CP Colonic ischemia: the Achilles heel of ruptured aortic aneurysm repair. Am Surg. 1996; 62:557-60.

25. Bjorck M, Troeng T, Bergqvist D. Risk-factors for intestinal ischaemia after aortoiliac surgery. A combined cohort and case-control study of 2824 operations. Eur J Vasc Endovasc Surg. 1997; 13:531-9.

26. Cabie A, Farkas JC, Fitting C, Laurian C, Cormier JM, Cavaillon JM. High levels of portal TNF-alpha during abdominal aortic surgery in man. Cytokine. 1993;5: 448-53.

27. Formigli L, Lombardo LD, Adembri C, Brunelleschi S, Ferrari E, Novelli GP. Neutrophils as mediators of human 
skeletal muscle ischemia-reperfusion syndrome. Hum Pathol. 1992; 23:627-34.

28. Novelli GP, Adembri C, Gandini E, Orlandini SZ, Papucci L, Formigli L, Manneschi LI, Quattrone A, Pratesi C, Capaccioli S. Vitamin E protects human skeletal muscle from damage during surgical ischemia-reperfusion. Am J Surg. 1997;173: 206-9.

29. Yassin MM, Barros D’Sa AA, Parks TG, McCaigue MD, Leggett P, Halliday MI, Rowlands BJ.. Lower limb ischaemia-reperfusion injury alters gastrointestinal structure and function. Br J Surg. 1997; 84:1425-9.

30. Corson RJ, Paterson IS, O’Dwyer ST, Rowland P, Kirkman E, Little RA, McCollum CN. Lower limb ischaemia and reperfusion alters gut permeability. Eur J Vasc Surg. 1992; 6:158-63.

31. Yassin MM, Barros D’Sa AA, Parks TG, Soong CV, Halliday MI, McCaigue MD, Erwin PJ, Rowlands BJ. Lower limb ischaemia-reperfusion injury causes endotoxaemia and endogenous antiendotoxin antibody consumption but not bacterial translocation. Br J Surg. 1998; 85:785-9.

32. Wehrens XH, Rouwet EV, oude Egbrink MG, Slaaf DW, Ramsay G. Effects of experimental lower-limb ischaemiareperfusion injury on the mesenteric microcirculation. Br J Surg. 2002 ; 89:185-91.

33. Francisco Neto A, Silva JC, Fagundes DJ, Percario S, Novo NF, Juliano Y, Moreira Neto AA. Oxidative alterations, total antioxidant status and nitric oxide study in rats submitted to ischemia and reperfusion of hind limbs. Acta Cir Bras. 2005; 20:134-9.

34. Baigrie RJ, Lamont PM, Whiting S, Morris PJ. Portal endotoxin and cytokine responses to abdominal aortic surgery. Am J Surg. 1993; 166:248-51.

35. Lau LL, Gardiner KR, Martin L, Halliday MI, Hannon RJ, Lee B, Soong CV. Extraperitoneal approach reduces neutrophil activation, systemic inflammatory response and organ dysfunctionin aortic aneurysm surgery. Eur J Vasc Endovasc Surg. 2001; 21:326-33.

36. Norwood MG, Bown MJ, Sutton AJ, Nicholson ML, Sayers RD. Interleukin 6 production during abdominal aortic aneurysm repair arises from the gastrointestinal tract and not the legs. Br J Surg. 2004; 91:1153-6.

37. Holzheimer RG, Gross J, Schein M. Holzheimer RB, Schein M. Pro- and anti-inflammatory cytokine-response in abdominal aortic aneurysm repair: a clinical model of ischemia-reperfusion. Shock. 1999; 11:305-10.

38. Illyes G, Hamar J. Sequence of morphological alterations in a small intestinal ischaemia/reperfusion model of the anesthetized rat. A light microscopy study. Int J Exp Pathol. 1992; 73:161-72.

39. de Aguilar-Nascimento JE, Gurgel Marques C, Carvalho Mariano A, Bicudo Salomao A, de Souza Neves J. Benefits of intraluminal injection of glutamine for intestinal mucosa during ischemia-reperfusion. Eur Surg Res. 2003; 35:352-6.

\section{Correspondence:}

Mr. M B P Pimenta

Rua Cursino do Amarante 1022 ap 401 Cuiabá, MT, Brazil

78045-390

Fax: +556536188263

Phone number: +556536188263

e-mail: $\underline{\text { mbpp@terra.com.br }}$
Conflict of interest: none Financial source: none 